\title{
ASSESSMENT OF KARST GEOMORPHOSITES ON KUČAJ AND BELJANICA MOUNTAINS AS A RESOURCE FOR THE DEVELOPMENT OF KARST-BASED GEOPARK
}

\author{
OVREDNOTENJE KRAŠKIH GEOMORFOLOŠKIH TOČK NA \\ OBMOČJU GORA KUČAJ IN BELJANICA KOT IZHODIŠČE ZA \\ USTANOVITEV GEOPARKA NA KRAŠKI OSNOVI
}

\author{
Aleksandar S. PETROVIĆ ${ }^{1, *}$, Dragana NIKOLIĆ ${ }^{2}$, \\ Dušica TRNAVAC BOGDANOVIĆ ${ }^{1}$ \& Ivana CAREVIĆ ${ }^{1}$
}

\begin{abstract}
UDC 551.44:719(497.11-751)

Aleksandar S. Petrović, Dragana Nikolić, Dušica Trnavac Bogdanović \& Ivana Carević: Assessment of karst geomorphosites on Kučaj and Beljanica mountains as a resource for the development of karst-based geopark

Protection and promotion of geoheritage has been changing and improving in recent decades, in line with the growing research in this field. Some research papers specifically study geomorphological geoheritage and introduce a special term geomorphosite. Karst geomorphosites present specific objects of geomorphological heritage. On Kučaj and Beljanica mountains there is the largest karst area in Serbia. The purpose of this paper is to select and evaluate the scientific value of karst geomorphosites of Kučaj and Beljanica. More than one hundred karst geomorphosites were analyzed. In order to achieve more adequate coverage and representation, they were grouped into 25 geomorphotypes in three major geomorphological components of the investigated area.

The results of this analysis highlighted the most important natural potentials of this area for establishing a karst-based geopark. More than 20 geomorphotypes have a positive recommendation index, which provides a good basis for further geotourism analysis.
\end{abstract}

Key words: karst geoheritage, geomorphosite, geomorphotype, geotourism, geopark, Carpatho-Balkanides, Serbia.
Izvleček

UDK 551.44:719(497.11-751)

Aleksandar S. Petrović, Dragana Nikolić, Dušica Trnavac Bogdanović \& Ivana Carević: Ovrednotenje kraških geomorfoloških točk na območju gora Kučaj in Beljanica kot izhodišče za ustanovitev geoparka na kraški osnovi

Zaščita in promocija geodediščine se $\mathrm{v}$ zadnjih desetletjih spreminjata in izboljšujeta, skladno s čedalje večjim številom tovrstnih raziskav. Nekateri raziskovalni članki posebej proučujejo geomorfološko geodediščino in uvajajo poseben izraz, geomorfološko točko. Kraške geomorfološke točke predstavljajo specifične cilje geomorfološke dediščine. Na gorah Kučaj in Beljanica je največje kraško območje v Srbiji. Namen prispevka je izbrati in ovrednotiti znanstveno vrednost kraških geomorfoloških točk Kučaja in Beljanice. Analiziranih je bilo več kot sto kraških geomorfoloških točk. Da bi se dosegli ustreznejša pokritost in zastopanost, so bile te točke združene v 25 geomorfoloških tipov treh glavnih geomorfoloških komponent raziskovalnega območja. Izsledki te analize so izpostavili najpomembnejše naravne potenciale tega območja za vzpostavitev geoparka na kraški osnovi. Več kot 20 geomorfoloških tipov ima pozitiven indeks priporočil, kar je dobro izhodišče za nadaljnjo analizo geoturizma.

Ključne besede: kraška geodediščina, geomorfološka točka, geomorfološki tip, geoturizem, geopark, Karpato-Balkanidi, Srbija.

\footnotetext{
${ }^{1}$ University of Belgrade, Faculty of Geography, Studentski trg 3/3, Belgrade, Serbia, e-mails: aleksandar.petrovic@gef.bg.ac.rs, trnavac@yahoo.com, ivana.carevic@gef.bg.ac.rs

${ }^{2}$ City Council of the Bor Municipality, Moše Pijade 3, Bor, e-mail: dragana.nikolic@bor.rs

* Corresponding Author
} 


\section{INTRODUCTION}

The karst on Kučaj and Beljanica mountains presents the largest integrated karst area of Serbia. It covers an area of over $850 \mathrm{~km}^{2}$, including a part of the Resava River upper basin. Furthermore, this is a completely uninhabited area because all settlements are distributed along the edges of the mountains (Fig. 1). Low human activity, reduced to basic animal husbandry and forestry, has led to the preservation of karst landscapes for which these mountains are known. Jovan Cvijić, the founder of karstology, also made his first steps in karst research on Kučaj, during excursions with the professors of the Belgrade Great School (Cvijić 1893).

The promotion of karst of this area has a tradition lasting about half a century. This especially applies to the opening of tourist caves during the 70s and 80s of the $20^{\text {th }}$ century (Lazarević 1981) and the landscape planning in the surroundings of karst springs for excursions and leisure tourism. However, in the last three decades, scientific research on geoheritage has increased worldwide (Brocx \& Semeniuk 2007), especially thanks to the initiatives that started with the establishment of ProGeo international body of geoconservation in 1993 (Wimbledon \& Smith-Meyer 2012). The concept of protection and promotion of geoheritage is changing and improving as the result of these research studies. Increasing attention is paid to the promotion of geoheritage through the development of geotourism, and geoparks are emerging as an ideal instrument for this (Ruban 2015, 2017). The concept of Geoparks, created within the UNESCO initiative, defines the geoparks as areas in which geoheritage has a particular value for education, science, culture and socio-economic development (UNESCO \& GGN 2010).

The basis on which geotourism develops are geosites which, regardless of whether a narrower or broader definition is observed (Grandgirard 1997; Brilha 2016), have significant scientific and educational value. A special type of geosites are geomorphosites, landforms that are part of the geomorphological heritage (Panizza 2001). Karst geomorphosites are a specific part of geomorphological geoheritage. Assessment and promotion of karst geoheritage and geomorphosites is the topic of recent studies (Martín-Duque et al. 2012; Hoblea et al. 2014; Miljković 2018; Antić et al. 2019).

Karst geoheritage as a resource is present in 22 geoparks of the UNESCO Global Geoparks, and 7 of them are fully karst-based Geoparks (Ruban 2018). In 2020, UNESCO announced another 15 new geoparks, including the Djerdap Geopark (UNESCO 2020). Djerdap Geopark is the first geopark in Serbia and it is partly karst-based. Only one karst geopark, Causses du Quercy, is situated in Europe. The purpose of this paper is to assess the karst geomorphosites of Kučaj and Beljanica mountains in order to start the initiative for establishing a karst-based geopark. Having in mind that geoparks have three important components scientificeducational, cultural and socio-economic, in this paper,

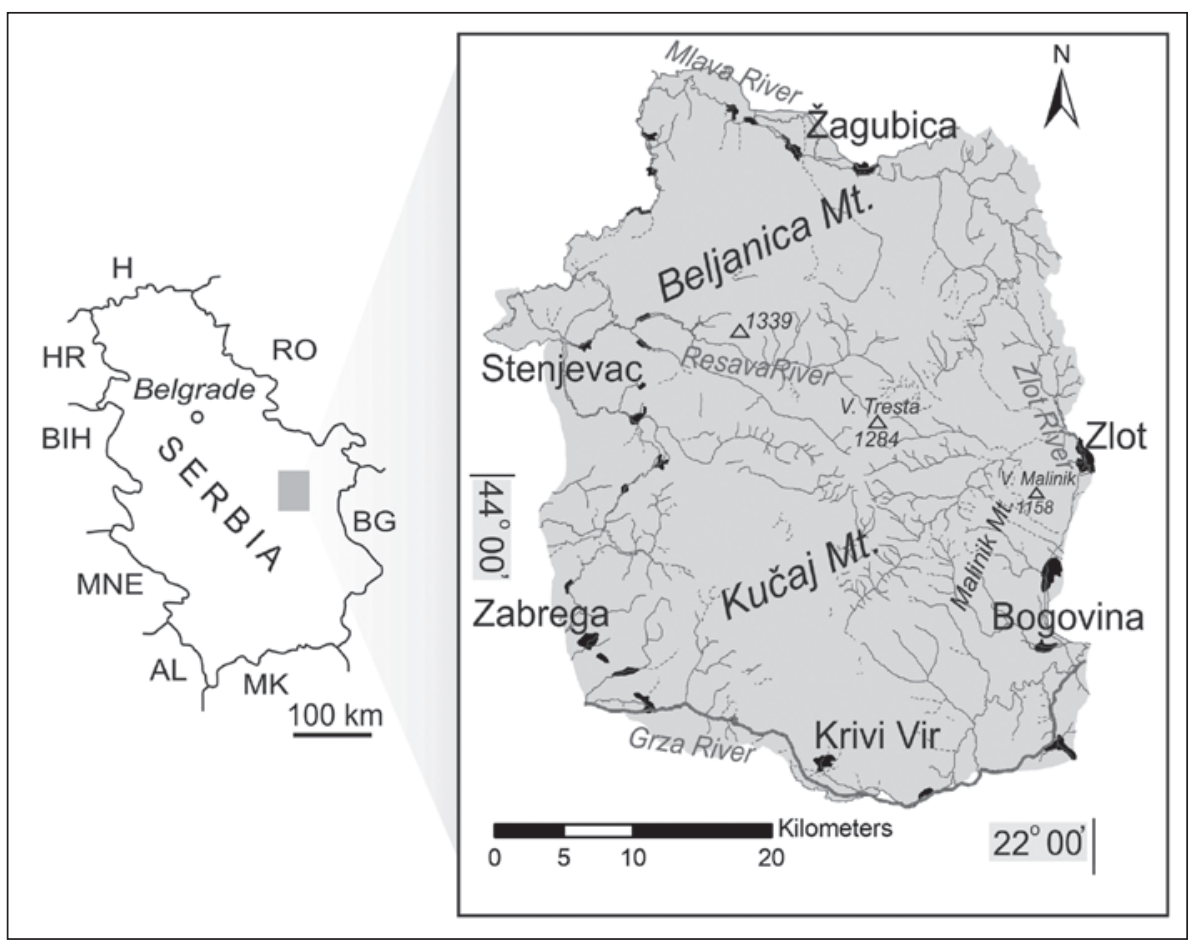

Fig. 1: Location map of the research area. 
the priority is given to the assessment of the scientificeducational aspect related to earth sciences. The results of this analysis highlight the most important natural potentials of this area for the establishment of a karstbased geopark and provide the basis for further geotourism analysis.

\section{GEOLOGICAL AND GEOGRAPHICAL SETTING}

Kučaj and Beljanica mountains are part of the Carpatho-Balkanides of eastern Serbia. They are located between the Žagubica basin and the Mlava River valley in the north, the Grza River and Crni Timok River valleys in the south, the Zlotska River valley in the east and Velika Morava River valley in the west. In the central west part, these two mountains are separated by the Resava River upper basin, while in the east they are orographically connected (Fig. 1).

Kučaj and Beljanica mountains belong to the Kučaj Terrane that corresponds to the Getic tectono-stratigraphic unit (Karamata \& Krstić 1996). The oldest rocks are composed of a Proterozoic volcano-sedimentary series metamorphosed under greenschist-facies conditions
(Beljanica Formation) (Antonijević et al. 1970). They represent a part of the old crystalline basement and are transgressively overlain by a Paleozoic succession with clastites, metamorphites and igneous bodies. Marine sedimentation started in the area during the Middle Jurassic, characterized by the accumulation of terrigenous and carbonate sediments (Carević et al. 2011). The Upper Jurassic is built up mostly of reef limestones conformably overlain by Cretaceous carbonate deposits. These are followed by the Barremian/Aptian limestones (Urgonian facies) (Carević et al. 2013). During the Late Jurassic-Early Cretaceous, a large part of the Getic domain consisted of shallow-water carbonate deposits (the Getic carbonate platform) preserved in the greatest area of Kučaj Mt. They

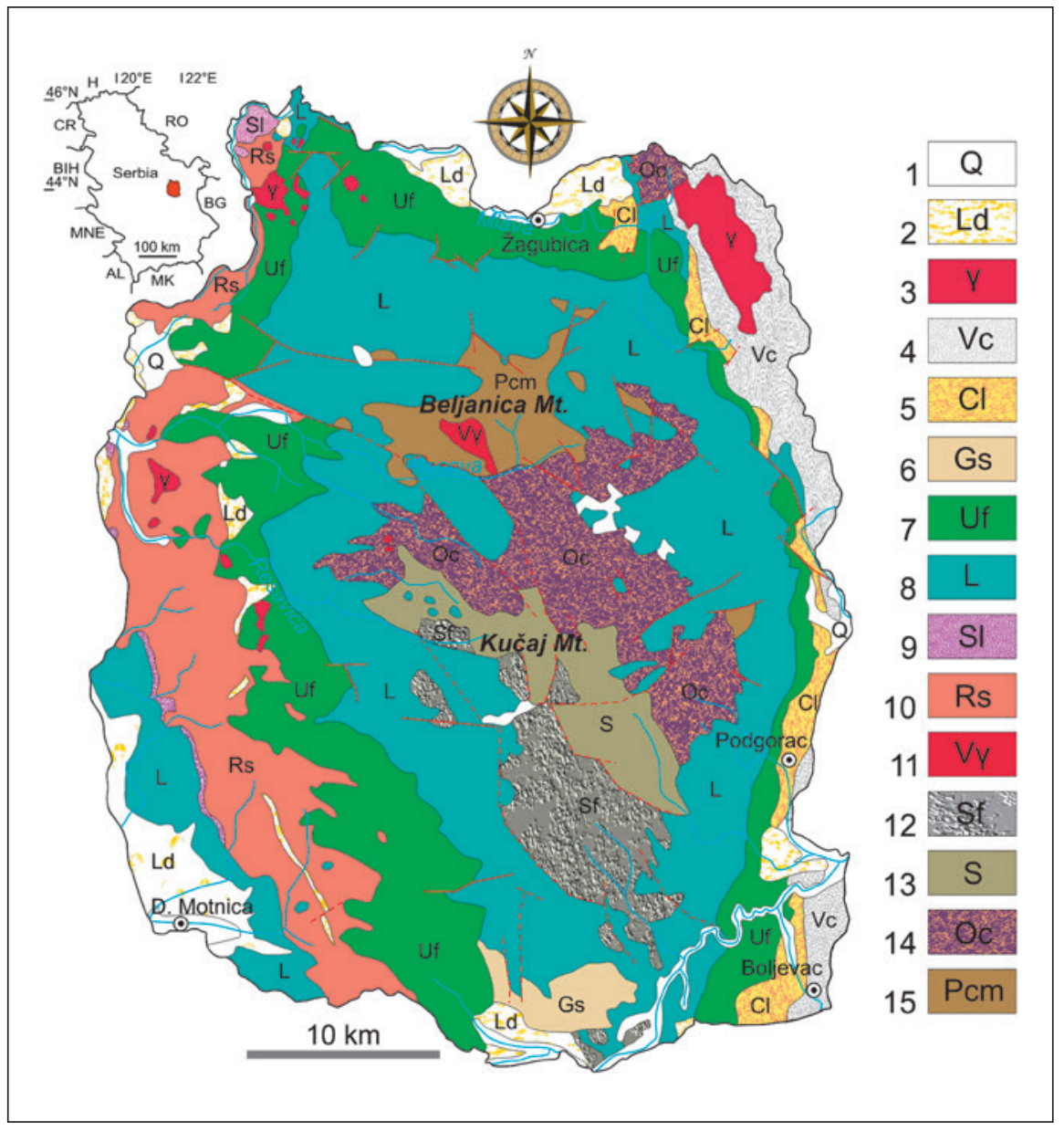

Fig. 2: Geological map of the wider area of the proposed karst-based geopark of Beljanica and Kučaj mountains (modified after Kräutner \& Krstić 2003). 1 - Quaternary deposits; 2 - Neogene lacustrine deposits; 3 Upper Cretaceous-Paleocene plutons and subvolcanic bodies: granodiorite, diorite, andesite, dacite; 4 - Turonian-Maastrichtian volcanoclastics: andesitic and dacitic agglomerate, volcanic breccia, tuffs; 5 - Turonian-Maastrichtian: conglomerates, sandstones, marls, marly and sandy limestones; 6 - Albian: glauconite sandstones; 7 - Barremian-Aptian (Urgonian facies): massive limestones; 8 - Doggerian-Hauterivian: stratified micritic limestones, locally with chert, marly limestones, marls, sandy limestones; 9 - Lower Triassic: sandy limestones; 10 - Permian: conglomerates, red sandstones; 11 - Upper Carboniferous: quartz-diorites, granodiorite, granite monzonite; 12 - Upper Devonian-Lower Carboniferous: sandy flysch; 13 - Silurian: graptolite schists - laminated thin bedded silty shales, black argillites; 14 - Ordovician: conglomerates, greywackes, sandstones, siltstones; 15 - Precambrian: Beljanica Formation - greenschists, "meta-keratophyres". 


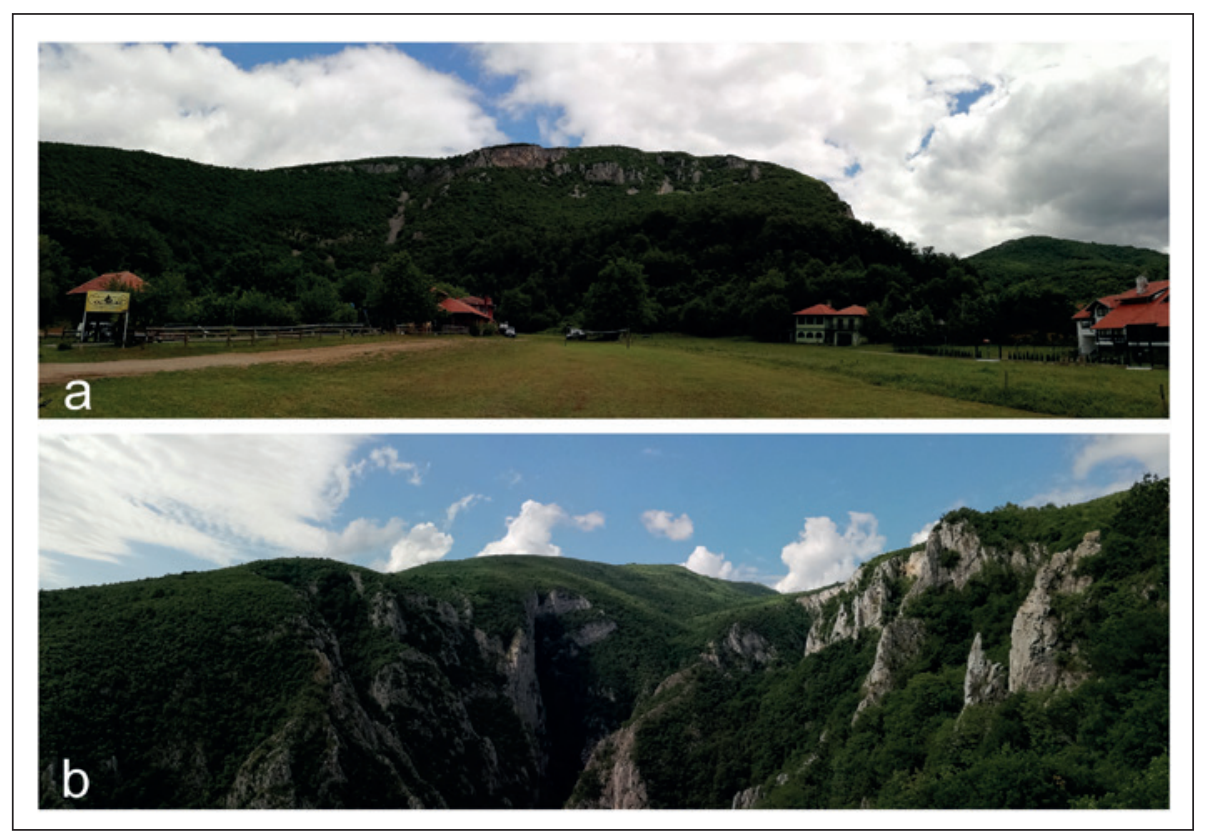

Fig. 3: a) Limestone escarpment on the southern rim of Beljanica; b) Canyon of Lazareva River (Photo: A. S. Petrović).

are unconformably overlain by Albian sandstones and Upper Cretaceous volcanoclastic-sedimentary Timok Group of Formations (Ljubović-Obradović et al. 2011). The Tertiary sedimentary cover is composed of Neogene lacustrine deposits (Fig. 2).

In the investigated area, three major geomorphological components are clearly distinguished from the north to the south: Beljanica mountain, the upper part of the Resava River basin and the Kučaj mountain. In all three geomorphological components, the karst relief is predominant.

Beljanica Mt. is an asymmetric anticline of the E-W direction. The northern slope of the mountain is gentle and descends towards the Žagubica valley. Several deep gorges were formed in it, and the deepest is Suvi Do. The relief of the northwestern part of Beljanica is dominated by a network of karst valleys. Epigenetic valley of the Tisnica River is cut in the northeastern edge of the mountain. The southern rim of Beljanica is represented by a limestone escarpment. It descends $600 \mathrm{~m}$ into the valley of the Resava River (Fig. 3a). Uvala-like depressions and smaller karst plateaus appear in the central part of Beljanica Mt.

The Resava River originates on the impermeable rocks of the central part of Kučaj Mt. Flowing through the limestone, it forms four deep gorges, the most impressive of which is the Sklop gorge. All tributaries of the Resava River also form deep gorges and canyons. There are several karst springs in the Resava valley. In the immediate vicinity of the Veliko Vrelo karst spring, a $20 \mathrm{~m}$ high tufa waterfall Lisine was formed.

Kučaj mountain is a plateau bordered on all sides by deep gorges or escarpments. It is only in the central part of the mountain that low peaks of non-carbonate rocks rise. The rivers formed in the central part of Kučaj cut deep gorges and canyons as they pass through the limestone. The canyon of the Lazareva River is the deepest on the mountain (Fig. 3b). Higher parts of Kučaj Mt. are karstified and divided into several karst plateaus (Dubašnica, Brezovica, Bele Vode). The most frequent features of karst relief are dolines, uvalas and various types of valleys in karst.

\section{METHODS}

In the literature of the last 20 years, a large number of papers dealing with the issue of geomorphosites assessment have appeared. Some authors have combined and compared methodologies for assessing the value of geomorphosites (Kubalikova 2013) for better visibility. The choice of a single method or a combination of several assessment methods depends on the purpose of the analysis. As the aim of this research is to assess the scientific value of the geomorphosites of Kučaj and Beljanica mountains for the purpose of future establishing of a karst-based geopark, an assessment procedure similar to that applied to Montesinho National Park was chosen (Pereira et al. 2007). It 
assumes two stages, with several sub-stages (Fig. 4). A specific methodology was chosen for each of them.

\begin{tabular}{|l|l|}
\hline Stages & Sub-stages \\
\hline Inventory & I) Identification of potential \\
& $\begin{array}{l}\text { II) } \begin{array}{l}\text { Seomorphosites } \\
\text { II) }\end{array} \\
\text { Qualitative assessment of } \\
\text { selected geomorphosites }\end{array}$ \\
\hline Quantification & III) Numerical assessment \\
\hline
\end{tabular}

Fig. 4: Stages and sub-stages in geomorphosite assessment (Pereira et al. 2007, modified).

The first phase was the creation of an inventory of karst geomophosites. It consisted of several sub-stages. The basis for the identification of potential geomorphosites sub-stage was the geomorphological information system (GmIS) of Kučaj Mt. and Beljanica Mt. made during previous research (Petrović 2015). The existing data in this GmIS (Petrović et al. 2015) have been complemented with new layers of data related to anthropogenic structures (settlements, roads, tourist infrastructure...) (Fig. 5). The formation of a large database of different data enabled, first of all, easier visualization of the layout of all potential geomorphosites in the researched area. GIS analysis of these data facilitated the work in the next sub-stage of the assessment.

The selection of geomorphosites sub-stage aims to reduce the list of potential karst geomorphosites to those for which quantitative analysis will be performed. The prepared inventory contains a large number of karst geomorphosites whose characteristics differ in size, genesis and representation. In order to avoid omitting certain geomorphosites that are close to the more dominant ones (e.g., unique ones), a deductive method

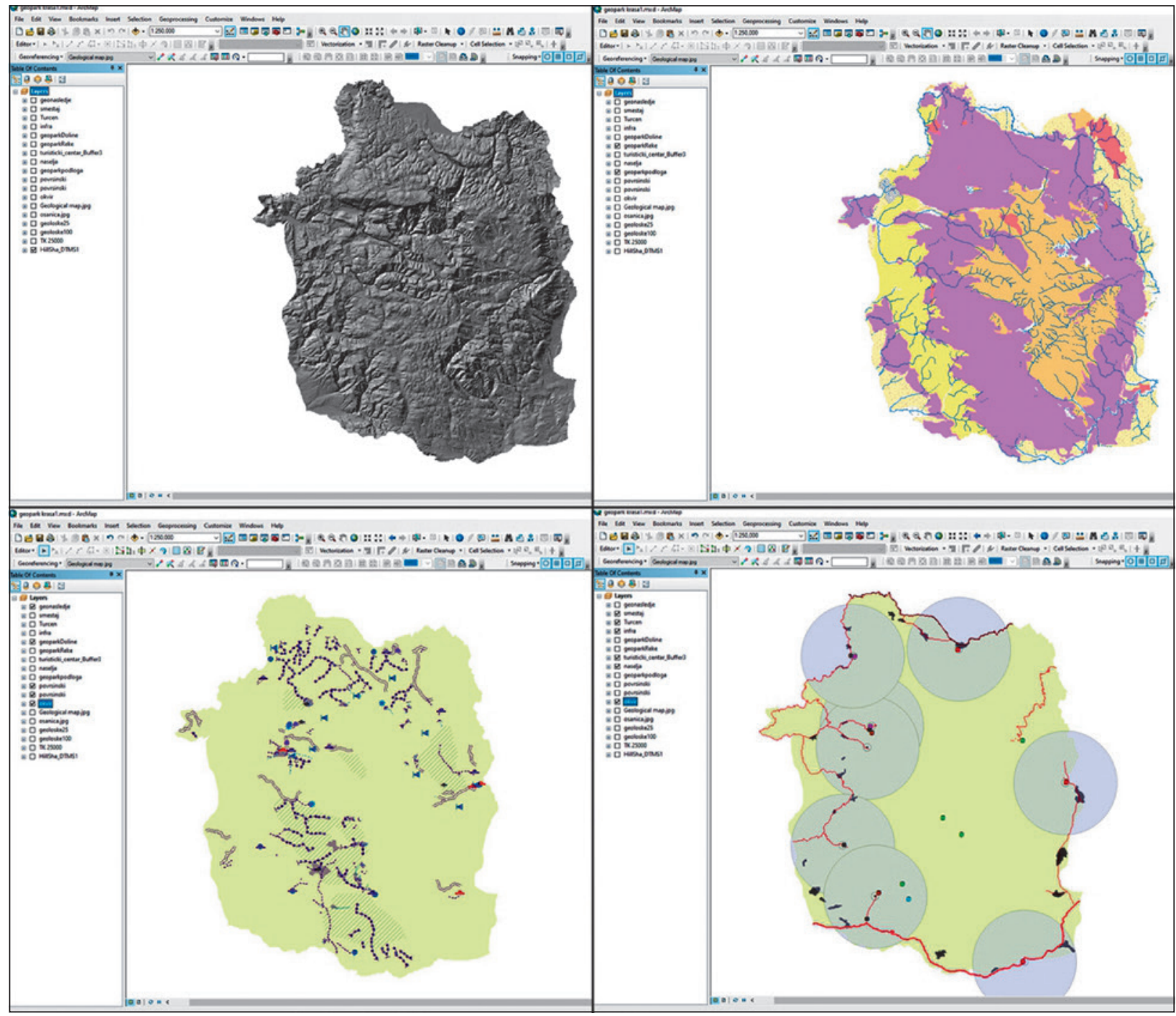

Fig 5: Working layers in GmIS of Kučaj-Beljanica karst area. 


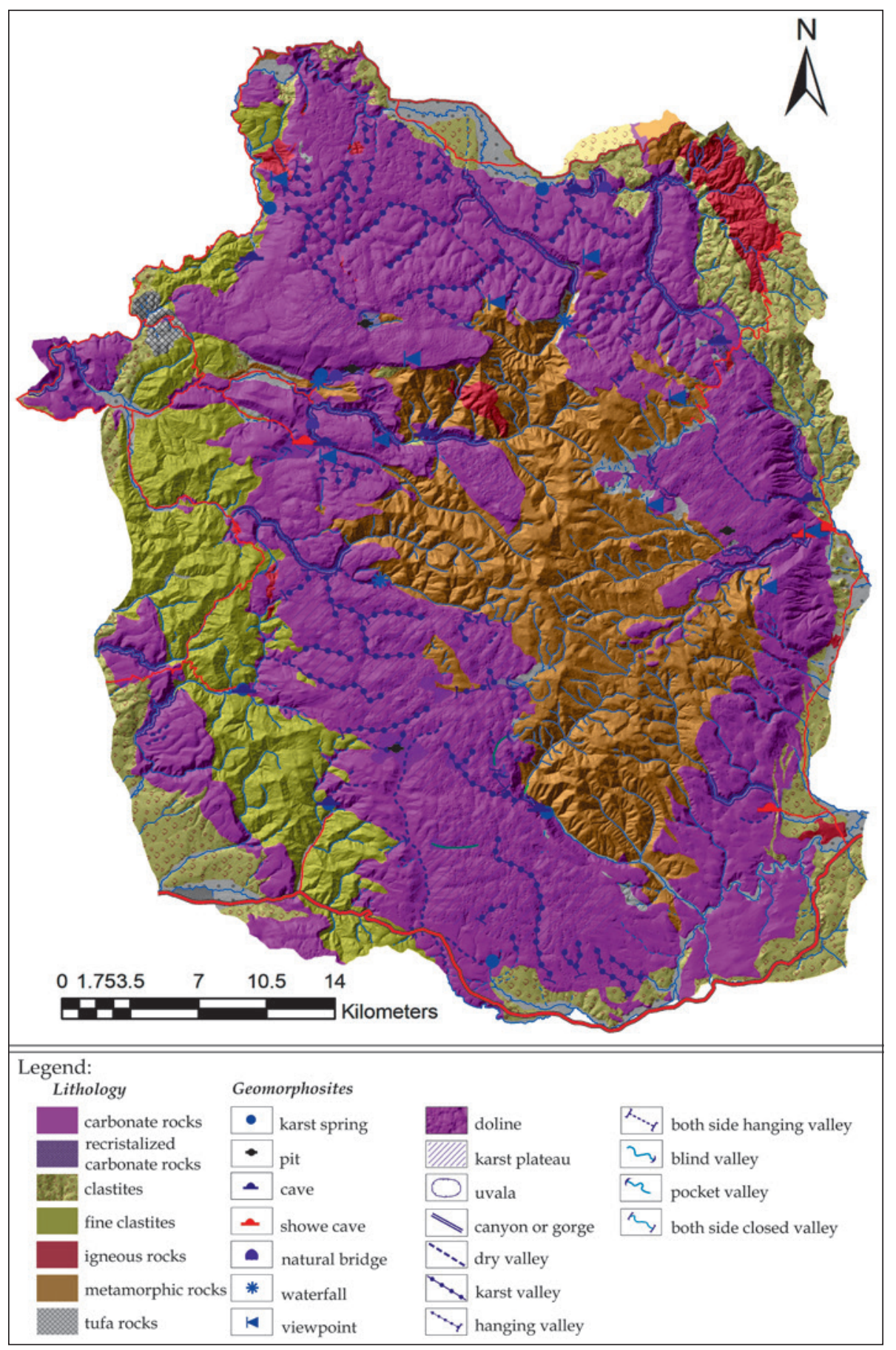

Fig. 6: Map of Beljanica-Kučaj karst area and marked geomorphotypes referring to Tab. 1 .

was chosen for the selection of geomorphosites (Sellier 2016). This method assumes first the definition of larger units, geomorphotypes, within each major geomorphological component. Geomorphotypes contain several geomorphosites, which together form one logical entity. According to the specifics of this analysis, all geomorphotypes represent groups of a maximum of 10 karst geomorphosites.

The selection of geomorphotypes and geomor- phosites within them was made on the basis of all data from GmIS, taking into account the representation, specificity, accessibility, visibility and distance from tourist sites. All geomorphosites that are represented in a smaller number have been retained, while a significant reduction has been made in those that are very numerous (valleys in karst, uvalas, etc.).

The qualitative assessment of potential geomorphosites sub-stage is based on a questionnaire similar to 
the one applied in the Tauzer region, South-West Tunisia (De Waele et al. 2005). The questionnaire was modified to provide the answers necessary for the second, quantitative stage of the assessment. The data entered in the questionnaire are the result of literature analysis, field research and GIS analysis of the existing GmIS of Kučaj and Beljanica mountains.

The second part was quantitative stage and involved numerical assessment. The method of assessment of the Scientific Quality of geomorphological sites was chosen for this (Coratzza 2005). This assessment assumes that Scientific Quality (Q) depends on several parameters, out of which geological and geomorphological knowledge of the study area is necessary, as well as the knowledge of the wider surroundings of the karst terrains of the Carpathian-Balkanides of Serbia. The parameters taken into account are: value for scientific research (S), educational value $(\mathrm{D})$, area $(\mathrm{A})$, rareness $(\mathrm{R})$, degree of conservation $(C)$, exposure $(E)$, added value $(Z)$. Numerical assessment for scientific quality was done according to the following formula:

$$
\mathrm{Q}=\mathrm{sS}+\mathrm{dD}+\mathrm{aA}+\mathrm{rR}+\mathrm{cC}+\mathrm{eE}+\mathrm{zZ}
$$

Where $S, D, A, R, C, E, Z$ are the values and $s, d, a, r$. c, e, $\mathrm{z}$ the respective weights (Coratzza 2005).

The parameters of value for scientific research (S), educational value (D) and rareness (R) are of the greatest importance for this analysis, so the respective weights for them are 1. Other parameters had respective weights of 0.5. Only the parameter area (A) had the smallest respective weights of 0.25 because the area of all geomorphotypes is disproportionately smaller than the analyzed karst area.

Numerical assessment was done for each individual geomorphosite within a particular geomorphotype. The Scientific Quality Index (Qn) for geomorphotypes was then calculated according to the formula $\mathrm{Qn}=\mathrm{Q} / \mathrm{Q} \max$, where $Q$ is scientific index and Qmax is maximal value of Q. The obtained values enabled the ranking of geomorphotypes.

Recommendation Index ( $\mathrm{Qr}$ ) is obtained by converting the $Q n$ value to 0 , if the values are less than 5 , or to 1 if the values are equal or greater than 5 . This index is an indicator of particular geomorphotype potential for further geotourism analysis.

\section{RESULTS AND DISCUSSION}

In all three major geomorphological components of Beljanica-Kučaj karst area, 25 geomorphotypes were selected (Fig. 6). Most of them are on the Kučaj mountain, where 13 geomorphotypes were selected. There are 8 of them on Beljanica, and 4 in the Resava River upper basin. A total of 124 geomorphosites were selected and analyzed. The number of geomorphosites per geomorphotype ranged from a maximum of 10 to a minimum of 3 geomorphosites.

On Beljanica-Kučaj karst area there are all 12 morphological types of valleys in karst defined in the related study by Petrović (2015). Some types of valleys are very
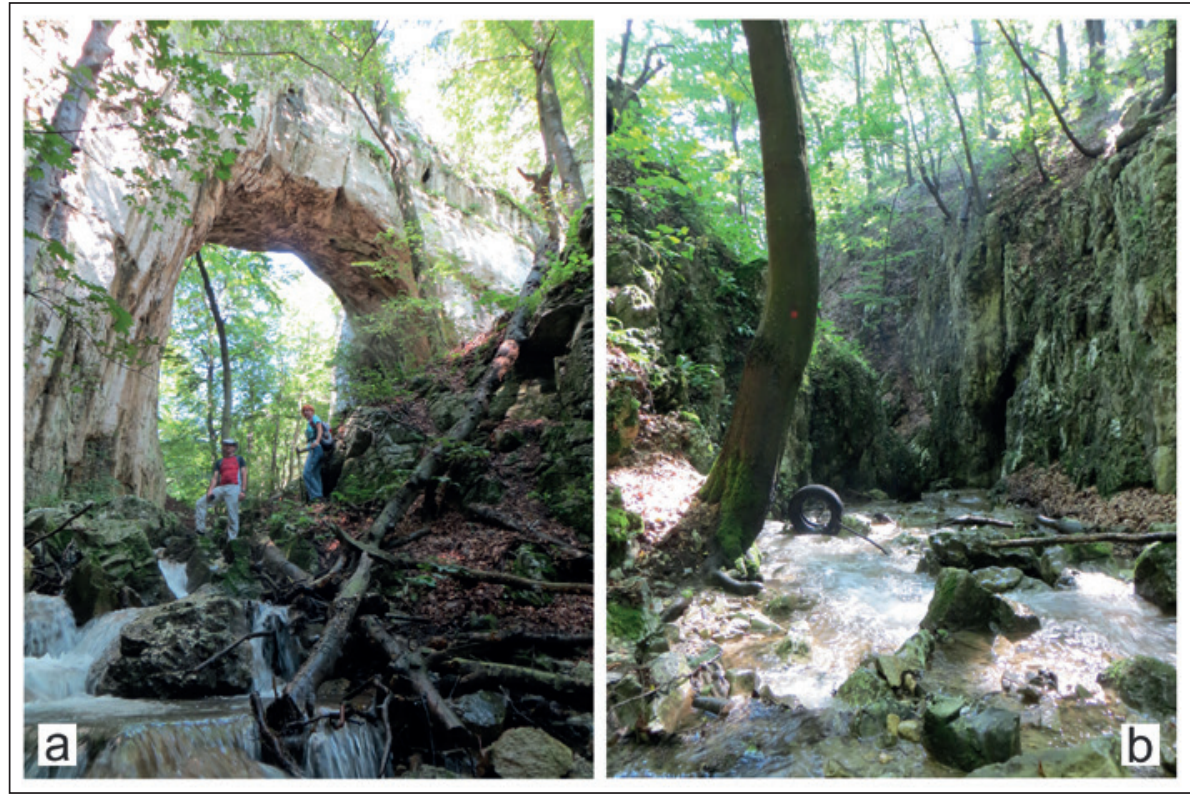

Fig. 7: a) Samar natural bridge; b) Ravna Reka River collapsed valley (Photo: A. S. Petrović). 
common (e.g., dry and blind valley) unlike others that occur in very small numbers (e.g., pocket or both side closed valley). During the selection of geomorphosites, the number of valleys in karst had to be reduced, for the reason of simplification. The specific ones were selected, those that occur in small numbers or those that are close to other important geomorphosites. However, valleys in karst are the most common type of karst geomorphosites. The dolines were not separately considered but were included within the karst plateaus.

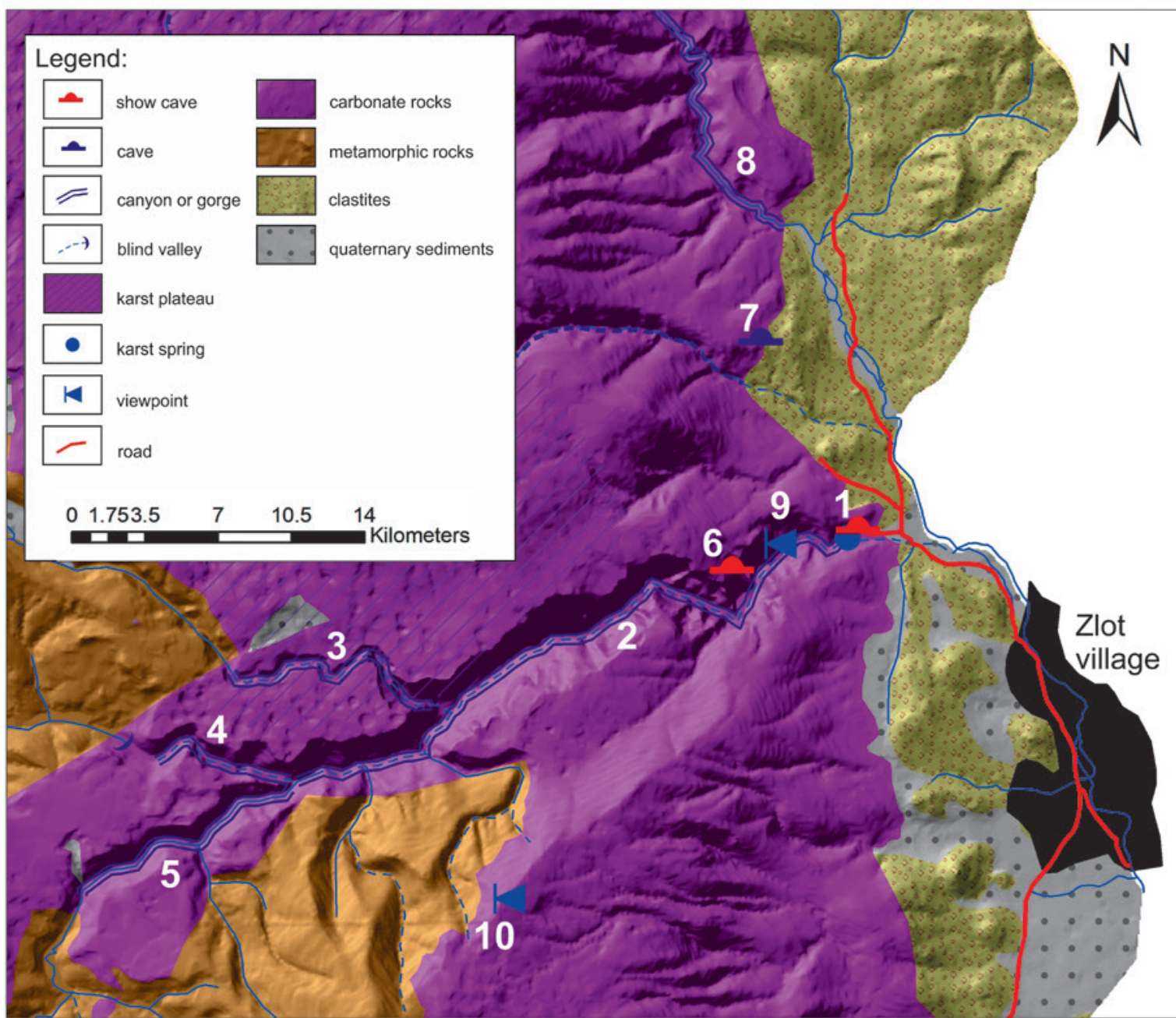

\begin{tabular}{|c|c|c|c|c|c|c|c|c|c|c|c|c|c|c|c|c|}
\hline Geomorphosite & $\mathbf{S}$ & sS & D & dD & A & $\mathrm{aA}$ & $\mathbf{R}$ & $\mathrm{rR}$ & C & cC & $E$ & eE & $\mathbf{Z}$ & $\mathbf{z Z}$ & Q & Qn \\
\hline \multicolumn{17}{|c|}{ Lazar river canyon } \\
\hline Zlot cave & 1 & 1 & 1 & 1 & 0.25 & 0.06 & 0.75 & 0.75 & 1 & 0.5 & 0.5 & 0.25 & 1 & 0.5 & 4.06 & 0.86 \\
\hline Lazar river canyon & 1 & 1 & 1 & 1 & 0.25 & 0.06 & 0.75 & 0.75 & 1 & 0.5 & 0.5 & 0.25 & 1 & 0.5 & 4.06 & 0.86 \\
\hline Mikulj river gorge & 0.75 & 0.75 & 0.5 & 0.5 & 0.25 & 0.06 & 0.5 & 0.5 & 1 & 0.5 & 0.75 & 0.38 & 0.5 & 0.25 & 2.94 & 0.62 \\
\hline De Mizlok river gorge & 0.75 & 0.75 & 0.5 & 0.5 & 0.25 & 0.06 & 0.5 & 0.5 & 1 & 0.5 & 0.75 & 0.38 & 0.5 & 0.25 & 2.94 & 0.62 \\
\hline Vej river gorge & 0.75 & 0.75 & 0.5 & 0.5 & 0.25 & 0.06 & 0.5 & 0.5 & 1 & 0.5 & 0.75 & 0.38 & 0.5 & 0.25 & 2.94 & 0.62 \\
\hline Vernjikica pit & 1 & 1 & 1 & 1 & 0.25 & 0.06 & 0.75 & \begin{tabular}{|l|l|} 
\\
\end{tabular} & 1 & 0.5 & 0.25 & 0.13 & 1 & 0.5 & 3.94 & 0.83 \\
\hline Mandina cave & 0.5 & 0.5 & 0.25 & 0.25 & 0.25 & 0.06 & 0.5 & 0.5 & 0.25 & 0.13 & 0.75 & 0.38 & 0.5 & 0.25 & 2.06 & 0.43 \\
\hline 8. $\quad$ Beljevina river gorge & 0.5 & 0.5 & 0.5 & 0.5 & 0.25 & 0.06 & 0.25 & 0.25 & 0.25 & 0.13 & 0.75 & 0.38 & 0.25 & 0.13 & 1.94 & 0.41 \\
\hline 9. Canyon viewpoint & 0.5 & 0.5 & 1 & 1 & 0.25 & 0.06 & 0.75 & 0.75 & 1 & 0.5 & 0.5 & 0.25 & 1 & 0.5 & 3.56 & 0.75 \\
\hline \multirow[t]{2}{*}{ 10. Malinik viewpoint } & 0.5 & 0.5 & 0.75 & 0.75 & 0.25 & 0.06 & 0.75 & 0.75 & 0.5 & 0.25 & 1 & 0.5 & 0.5 & 0.25 & 3.06 & 0.64 \\
\hline & & & & & & & & & & & & & & & 3.15 & 0.66 \\
\hline
\end{tabular}

Fig. 8: Map of Lazar River canyon geomorphotype and quantitative assessment of the scientific quality of the geomorphosites within it. 
Only two geomorphosites got the highest rating in terms of uniqueness. Both are located within the Samar geomorphotype (Fig. 6, No. 3, north-eastern part). These are Samar natural bridge (Fig. 7a) and Ravna Reka River collapsed valley (Fig. 7b) (Petrović \& Carević 2015).

Geomorphotypes were singled out by grouping geomorphosites related to individual dominant karst forms. The Lazar River canyon geomorphotype (Fig. 8) is an excellent example of such grouping. The canyon (Fig. 8) and Lazareva Pećina Cave represent the most valuable geomorphosites of this geomorphotype, which is indicated within their assessment (Fig. 8). However, within the canyon and in the surrounding area there are several other important geomorphosites of great scientific and educational value. Of all geomorphotypes of Beljanica and Kučaj, Lazar River canyon has been the most valorized for geotourism purposes so far (Tomić 2011; Tomić \& Božić 2014).
The quantitative assessment of the Scientific Quality of geomorphotypes was performed using data from the qualitative assessment of each individual geomorphosite. First, a numerical assessment was performed for all geomorphosites of one geomorphotype (e.g., table in Fig. 8), and then the mean value for Scientific Quality (Q), Scientific Quality Index (Qn) and Recommendation Index (Qr) was calculated for each geomorphotype respectively (Tab. 1a).

The analysis of the obtained results points to several important conclusions. First, only three geomorphotypes have a recommendation index (Qr) of 0 (Tab. 1a). All others have significant scientific and educational potential. Within this group, individual geomorphotypes stand out (Tab. 1a). Considering geomorphosites, this potential is currently used in only a few of them (Lazar River Canyon, Mlava and Krupaja karst springs), which are often the destination of field classes for geography and geology students

Tab. 1: a) scientific quality indicators of geomorphotypes; b) scientific quality indicators of the best ranked geomorphosites.

a)

\begin{tabular}{|c|c|c|c|c|}
\hline $\begin{array}{l}\text { Major geomor- } \\
\text { phological com- } \\
\text { ponent }\end{array}$ & Geomorphotype & Q & Qn & Qr \\
\hline \multirow{13}{*}{ Kučaj Mt. } & 1. Lazar River canyon & 3.15 & 0.66 & 1 \\
\hline & 2. Dubašnica & 2.79 & 0.59 & 1 \\
\hline & 3. Samar & 3.23 & 0.68 & 1 \\
\hline & 4. Brezovica & 2.42 & 0.51 & 1 \\
\hline & 5. Valka Luce & 2.33 & 0.49 & 0 \\
\hline & 6. Nekudovo - Resavica & 2.75 & 0.58 & 1 \\
\hline & 7. Dobra Voda & 2.26 & 0.48 & 0 \\
\hline & 8. Central Kučaj & 2.48 & 0.52 & 1 \\
\hline & 9. Radovanska River valley & 2.6 & 0.55 & 1 \\
\hline & 10. Bogovina & 2.88 & 0.61 & 1 \\
\hline & 11. South Kučaj & 2.54 & 0.54 & 1 \\
\hline & 12. Grza & 2.75 & 0.58 & 1 \\
\hline & 13. Sisevac & 2.78 & 0.59 & 1 \\
\hline \multirow{8}{*}{ Beljanica Mt. } & 14. Mlava karst spring & 2.81 & 0.59 & 1 \\
\hline & 15. Suvi do & 3.06 & 0.64 & 1 \\
\hline & 16. Krupaja & 3.25 & 0.68 & 1 \\
\hline & 17. Tisnica & 3.03 & 0.64 & 1 \\
\hline & 18. Uvala Rečke Žagubičke & 2.44 & 0.51 & 1 \\
\hline & 19. Beljanica ridge & 2.63 & 0.55 & 1 \\
\hline & 20. Western Beljanica & 2.19 & 0.46 & 0 \\
\hline & 21. Stenjka & 2.48 & 0.52 & 1 \\
\hline \multirow{4}{*}{$\begin{array}{l}\text { Upper Resava } \\
\text { River basin }\end{array}$} & 22. Lisine & 3.1 & 0.65 & 1 \\
\hline & 23. Resavska Cave & 2.83 & 0.6 & 1 \\
\hline & 24. Vita Bukva & 2.86 & 0.6 & 1 \\
\hline & 25. Vinatovača & 2.49 & 0.52 & 1 \\
\hline
\end{tabular}

b)

\begin{tabular}{|l|l|l|}
\hline Geomorphosite & Q & Qn \\
\hline Samar natural bridge & 4.19 & 0.88 \\
\hline Lazar River canyon & 4.06 & 0.88 \\
\hline Lazareva Pećina Cave & 4.06 & 0.86 \\
\hline Vernjikica Cave & 3.94 & 0.83 \\
\hline Ravna River collapsed valley & 3.94 & 0.83 \\
\hline Bogovina Cave & 3.94 & 0.83 \\
\hline Resavska Cave & 3.94 & 0.83 \\
\hline Prskalo tufa waterfall & 3.69 & 0.78 \\
\hline $\begin{array}{l}\text { Lisine tufa waterfall Canyon } \\
\text { viewpoint }\end{array}$ & 3.56 & 0.75 \\
\hline Mlava River karst spring & 3.56 & 0.75 \\
\hline Krupaja River karst spring & 3.56 & 0.75 \\
\hline Ivkov Ponor Cave & 3.56 & 0.75 \\
\hline Grza River karst spring & 3.44 & 0.72 \\
\hline Tisnica epigenetic valley & 3.44 & 0.72 \\
\hline Crni Timok pocket valley & 3.31 & 0.7 \\
\hline Crnica River karst spring & 3.31 & 0.7 \\
\hline Beljanički Buk karst spring & 3.31 & 0.7 \\
\hline Beljanički Buk tufa waterfall & 3.31 & 0.7 \\
\hline Tisnica natural arc & 3.31 & 0.7 \\
\hline Divljakovac & 3.31 & 0.7 \\
\hline
\end{tabular}




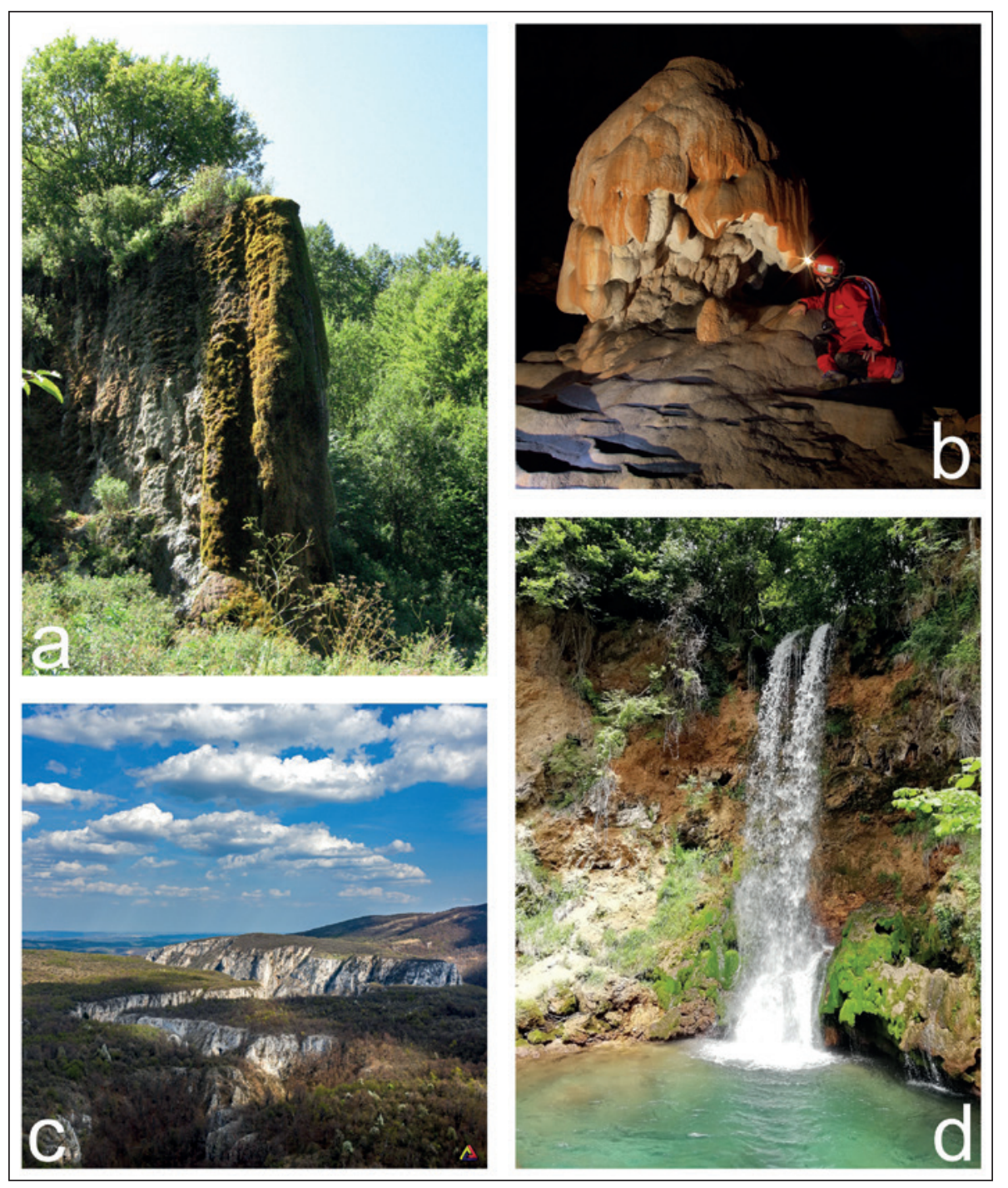

Fig. 9: Geomorphosites: a) Prskalo tufa waterfall; b) Vernjikica Cave; c) Valja Mikulj and Lazar Canyon from Kršijora viewpoint; d) Lisine tufa waterfall (Photos: A. S. Petrović (a-b, d); U. Načić (c)).

from Serbian universities. The scientific and educational potential of Resavska Cave geomorphosite is reather high because it is in the itinerary of school excursions.

Grouping of geomorphosites into geomorphotypes led to a decrease in $\mathrm{Q}$ values. Leading geomorphosites have a significantly better score than the average for the whole geomorphotype. The mean Q value for the Samar geomorphotype is 3.15 whereas for the Samar natural bridge geomorphosite it is 4.19 (Tab. 1b). Some geomorphosites, such as Prskalo waterfalls (Fig. 9), with their high $\mathrm{Q}$ value raised the mean $\mathrm{Q}$ value for the whole geomorphotype, which made its $\mathrm{Qr}$ value positive. This should be taken into account when geotourism analysis and valorization of geomorphotypes is done in the future.

Tab. $1 \mathrm{~b}$ shows only the best rated geomorphosites in this area. High values of Q and Qn indicate their scientific and educational importance. Most of them are referenced in a large number of scientific papers and protec- tion studies. Some geomorphosites (e.g., Tisnica epigenetic valley) are not sufficiently valorized for educational purposes. Tisnica epigenetic valley, despite its excellent position, has a lower grade due to the large anthropogenic impact (the existence of quarries within the gorge).

During the assessment of scientific value, the current state of certain geomorphosites was not taken into account. Vernjikica show cave (Fig. 9) is currently closed and is banned for visitors. Increasing security in this cave requires significant financial investment. It is similar with majority of other tourist caves in this area (Resavska, Lazareva, Bogovinska caves). All of them must significantly improve services and facilities for major tourism development (Tomić et al. 2019).

Improving the degree of conservation and renewal of earlier tourist capacities, as part of the added value, would significantly increase the value of certain geomorphotypes and geomorphosites within them. 


\section{CONCLUSIONS}

The concept of geotourism has been accepted in Serbia during the last decade. The number of scientific and professional papers on the topic of geodiversity, geosite assessment and geotourism development is constantly increasing. The first geopark in Serbia - Djerdap Geopark was officially declared by the UNESCO GGN in July 2020. The karst area of Kučaj and Beljanica mountains with its geodiversity values should be taken into consideration by the related state authorities as a candidate for a new karst-based geopark.

The conducted research has shown that in this area there are hundreds of geomorphosites suitable for future geotourism assessment and promotion. For the purposes of this research, they were grouped into larger units, geomorphotypes. The good side of this grouping is that these units also include objects of geomorphological geoheritage that would not be added to geotourism potential on their own. They do have the scientific and educational value, but their connection with the nearby dominant geomorphosites would be crucial in increasing their attractiveness for school and university excursions and field trips.

Bearing in mind that this is a rural area, non-industrialized, with a number of protected zones, the advantages of the concept of regional development through the establishment of a geopark are obvious. The benefit would be the promotion of karst geodiversity, with a strong accent on the sustainable economic development and the improvement of local population life in the karst area.

\section{ACKNOWLEDGEMENT}

Two anonymous reviewers are thanked for valuable corrections and helpful comments that helped to improve the original manuscript. The research was supported by the Ministry of Education, Science and Technological Development of the Republic of Serbia, Project No. 176017 (grant to IC) and Project No. 177023 (grant to AP).

\section{REFERENCES}

Antić, A., Tomić, N., \& S. Marković, 2019: Karst geoheritage and geotourism potential in the Pek River lower basin (Eastern Serbia).- Geographica Pannonica, 23, 1, 32-46. https://doi.org/10.5937/gp23-20463

Antonijević, I., Veselinović, M., Đorđević, M., Kalenić, M., Krstić, B. \& Lj. Karajičić, 1970: Explanatory booklet, Sheet Žagubica, Basic Geological Map 1:100 000.- Belgrade.

Brilha, J., 2016: Inventory and Quantitative Assessment of Geosites and Geodiversity Sites: A Review.Geoheritage, 8, 119-134. https://doi.org/10.1007/ s12371-014-0139-3

Brocx, M. \& V. Semeniuk, 2007: Geoheritage and geoconservation - history, definition, scope and scale.Journal of the Royal Society of Western Australia, 90, 2, 53-87.

Carević, I., Radulović, B., Ljubović-Obradović, D. Rabrenović, D. \& V. Jovanović, 2011: First record of the Middle Jurassic macrofauna from the Brnjica (NE Serbia): stratigraphy, palaeoecology and correlation with adjacent regions.- Neues Jahrbuch für Geologie und Paläontologie - Abhandlungen, 260, 3, 365-379. https://doi.org/10.1127/0077$7749 / 2011 / 0148$

Carević, I., Taherpour Khalil Abad, M., LjubovićObradović, D., Vaziri, S.H., Mirković, M., Aryaei, A.A., Stejić, P. \& A.R. Ashouri, 2013: Comparisons between the Urgonian platform carbonates from eastern Serbia (Carpatho-Balkanides) and northeast Iran (Kopet-Dagh Basin): Depositional facies, microfacies, biostratigraphy, palaeoenvironments and palaeoecology.- Cretaceous Research, 40, 110130. https://doi.org/10.1016/j.cretres.2012.06.003

Cvijić, J., 1893: Geografska proučavanja u oblasti Kučaja u Istočnoj Srbiji.- Geološki anali Balkanskog poluostrva, 1, 5, 4-172.

Grandgirard, V., 1997: Géomorphologie, protection de la nature et gestion du paysage.- $\mathrm{PhD}$ thesis, Faculté des Sciences, Université de Fribourg, pp. 258.

Hoblea, F., Delannoy, J.J., Jaillet, S., Ployon, E. \& B. Sadier, 2014: Digital Tools for Managing and Promoting Karst Geosites in Southeast France.- Geoheritage, 6, 
113-127. https://doi.org/10.1007/s12371-014-01121

De Waele, J., Di Gregorio, F., Gasmi, N., Melis, M.T. \& M. Talbi, 2005: Geomorphosites of Touzer gerion (South-west Tunisia).- Italian Journal of Quaternary Sciences, 18, 1, 221-230.

Karamata, S. \& B. Krstić, 1996: Terranes of Serbia and neighbouring areas.- In: Knežević-Djordjević, V. \& B. Krstić (eds.) Terranes of Serbia. The formation of the geologic framework of Serbia and the adjacent regions. University of Belgrade, Faculty of Mining and Geology, pp. 25-40, Belgrade.

Kräutner, H.G. \& B.P. Krstić, 2003: Geological map of the Carpatho-Balkanides between Mehadia, Oravita, Niš and Sofia, 1:300,000.- Belgrade.

Kubalíkova, L., 2013: Geomorphosite assessment for geotourism purposes.- Czech Journal of Tourism, 2, 2, 80-104. https://doi.org/10.2478/cjot-2013-0005

Lazarević, R., 1981: Uređenje pećina u turističke svrhe.Osmi jugoslovanski speleološki kongres, 1980, Borsko jezero, 147-154, Belgrade.

Ljubović-Obradović, D., Carević, I., Mirković, M. \& N. Protić, 2011: Upper Cretaceous volcanoclastic-sedimentary formations in the Timok Eruptive Area (eastern Serbia): new biostratigraphic data from planktonic foraminifera.- Geologica Carpathica 62, 5, 435-446. https://doi.org/10.2478/v10096-011-0031-x

Martín-Duque, J.F., Caballero García, J., \& L. Carcavilla Urquí, 2012: Geoheritage information for Geoconservation and Geotourism Through the Categorization of Landforms in a Karstic Landscape. A Case Study from Covalagua and Las Tuerces (Palencia, Spain).- Geoheritage, 4, 1-2, 93-108. https://doi. org/10.1007/s12371-012-0056-2

Miljković, Đ., 2018: Geomorphological and hydrological geoheritage of Homolje area.- $\mathrm{PhD}$ thesis. University of Novi Sad, Faculty of Science, pp. 392.

Panizza, M., 2001: Geomorphosites: Concepts, methods and examples of geomorphological survey.- Chinese Science Bulletin, 46, 4-5.

Pereira, P., Pereira, D., \& M.I. Caetano Alves, 2007: Geomorphosite assessment in Montesinho Natural Park.- Geographica Helvetica, 62, 3, 159-168. https://doi.org/10.5194/gh-62-159-2007

Petrović, S.A. \& I. Carević, 2015: Geological influence on the formation of Samar natural bridge and collapse valley of Ravna River from the NE Kučaj Mountains (Carpatho-Balkanides, eastern Serbia).- Acta Carsologica, 44, 1, 37-46. https://doi.org/10.3986/ac.v44i1.898

Petrović, S.A., 2015: Influence of modifiers on the polymorphism of valleys in karst

of the Serbian Carpatho-Balkanides.- $\mathrm{PhD}$ thesis. University of Belgrade, Geography faculty, pp. 264.
Petrović, S.A., Gajović, V. \& R. Veselinović, 2015: Upotreba geomorfološkog informacionog sistema na primeru kraških celina Karpato-balkanida Srbije.- In: Univerzitet u Beogradu, Geografski fakultet, Srpsko geografsko društvo Četvrti srpski kongres geografa aktuelnosti $i$ izazovi geografske nauke i prakse, $7^{\text {th }}$ $9^{\text {th }}$ October 2015, Kopaonik, 59-63, Belgrade.

Ruban, D.A., 2015: Geotourism - A geographical review of the literature.- Tourism Management Perspectives, 15, 1-15. https://doi.org/10.1016/j. tmp.2015.03.005

Ruban, D.A., 2017: Geodiversity as a precious national resource: A note on the role of geoparks.- Resources Policy, 53, C, 103-108. https://doi.org/10.1016/j.resourpol.2017.06.007

Ruban, D.A., 2018. Karst as Important Resource for Geopark - Based Tourism: Current State and Biases.- Resources, 7, 4, 82. https://doi.org/10.3390/ resources7040082

Sellier, D., 2016: A Deductive Method for the Selection of Geomorphosites: Application to Mont Ventoux (Provence, France).- Geoheritage, 8, 15-29. https:// doi.org/10.1007/s12371-015-0144-1

Tomić, N., 2011: The potential of Lazar Canyon (Serbia) as a geotourism destination: inventory and evaluation.- Geographica Pannonica, 15, 3, 103-112. https://doi.org/10.5937/GeoPan1103103T

Tomić, N. \& S. Božić, 2014: A modified geosite assessment model (MGAM) and its application on the Lazar Canyon area (Serbia).- International Journal of Environmental Research, 8, 4, 1041-1052. https:// doi.org/10.22059/ijer.2014.798

Tomić, N., Antić, A., Marković, S., Đorđević, T., Zorn, M. \& M. Breg Valjavec, 2019: Exploring the Potential for Speleotourism Development in Eastern Serbia.Geoheritage, 11, 359-369. https://doi.org/10.1007/ s12371-018-0288-x

UNESCO \& GGN, 2010: Guidelines and Criteria for National Geoparks Seeking Unesco's Assistance to Join The Global Geoparks Network (GGN).- [Online] Available from: http://www.europeangeoparks.org/ wp-ontent/uploads/2012/03/Geoparks_Guidelines_Jan2014.pdf [Accessed 3rd March 2020].

UNESCO, 2020: List of UNESCO Global Geoparks (UGGp).- [Online] Available from: http://www. unesco.org/new/en/natural-sciences/environment/ earth-sciences/unesco-global-geoparks/list-ofunesco-global-geoparks/ [Accessed 3rd September 2020].

Wimbledon, W.A.P. \& S. Smith-Meyer (eds.), 2012: Geoheritage in Europe and its conservation.- ProGEO, pp. 405, Oslo. 